\title{
Peningkatan Kualitas SDM Dalam Mendukung Pengembangan Desa Wisata Banjarsari Kecamatan Manyar Kabupaten Gresik
}

\author{
Noerchoidah ${ }^{1}$, Evita Purnaningrum ${ }^{2}$, Rina Fariana ${ }^{3}$, Subakir ${ }^{4}$ \\ 1,2 Program Studi Manajemen, Fakultas Ekonomi dan Bisnis, Universitas PGRI Adi Buana Surabaya \\ ${ }^{3,4}$ Program Studi Akuntansi, Fakultas Ekonomi dan Bisnis, Universitas PGRI Adi Buana Surabaya \\ Email: noerchoidah@unipasby.ac.id
}

\begin{abstract}
ABSTRAK
Mengembangkan sektor pariwisata merupakan salah satu cara untuk mendorong pertumbuhan ekonomi. Sektor pariwisata memiliki peran cukup besar dalam peningkatan pendapatan nasional, memberikan kesempatan bekerja, meningkatkan kesejahteraan, dan mendorong produk daerah dikenal secara internasional.

Pengembangan wisata tidak hanya di perkotaan namun bisa dilakukan di wilayah obyek tujuan wisata. Desa wisata merupakan salah satu wisata alternatif dalam sektor pariwisata. Desa Banjarsari Kecamatan Manyar Kabupaten Gresik memiliki potensi sebagai desa wisata. Permasalahan yang dihadapi dalam usaha pengembangan sebagai desa wisata belum tersedianya sumber daya manusia yang berkualitas seperti: ketrampilan, kemampuan, dan pengetahuan yang berkaitan dengan desa wisata belum dimiliki.

Kegiatan pengabdian kepada masyarakat ini dilakukan dengan tujuan untuk membantu masyarakat dalam meningkatkan kualitas sumber daya manusia di Desa Banjarsari Kecamatan Manyar Kabupaten Gresik sebagai desa wisata dengan memberikan penyuluhan dan pelatihan. Penyuluhan tentang kualitas pelayanan kepada wisatawan (seperti: penyediaan sarana dan prasarana, meningkatkan kemampuan berkomunikasi yang baik), pelatihan kuliner (seperti: pembuatan pudak dan bandeng) serta pembuatan website. Kegiatan pelatihan dan penyuluhan mendapatkan respon positif dari masyarakat untuk berkembangnya desa wisata.
\end{abstract}

Kata kunci: Kualitas sumber daya manusia, desa wisata, penyuluhan, pelatihan

\section{ABSTRACT}

Developing the tourism sector is one way to encourage economic growth. The tourism sector has a large enough role in increasing national income, providing employment opportunities, increasing welfare, and encouraging regional products to be known internationally.

Tourism development is not only in urban areas but can be done in tourist destination areas. Tourism village is alternative tourism in the tourism sector. The problems faced in Banjarsari Village, Manyar District, Gresik Regency in the development effort as a tourist village have not prepared quality human resources such as skills, abilities, and knowledge related to tourism villages are not yet possessed.

This activity is carried out to assist the community in improving the quality of human resources in Banjarsari Village, Manyar District, Gresik Regency as a tourist village by providing counseling and training. Outreach on the quality of services to tourists (such as the provision of facilities and infrastructure, improving good communication skills), culinary training (such as making pudak and milkfish), and creating websites. Training and extension activities received a positive response from the community for the development of a tourist village.

Keywords: quality of human resources, tourism village, counseling, training 


\section{PENDAHULUAN}

Kemajuan suatu wilayah dapat dilihat dari berbagai faktor, seperti perkembangan ekonomi, kondisi sosial, lingkungan maupun kelembagaannya. Faktor ekonomi paling dominan mempengaruhi kemajuan suatu wilayah tersebut (Nourse, 1968). Kemajuan sektor ekonomi sebagian dipengaruhi keberadaan pariwisata. Kontribusi sektor pariwisata terhadap PDB setiap tahun mengalami peningkatan. Pada tahun 2019 sektor pariwisata berkontribusi pada PDB sebesar 4,8\% lebih besar 0,3\% dibandingkan pada tahun 2018 (Kementrian Pariwisata, 2020). Keberadaan pariwisata dapat meningkatkan perekonomian suatu negara maupun masyarakat suatu daerah dan menciptakan lapangan kerja baru dalam mengurangi pengganguran yang terjadi di suatu daerah atau wilayah. Sektor pariwisata di Indonesia memiliki potensi besar untuk berkembang dengan kekayaan alam yang dimiliki memiliki potensi untuk dikembangkan sebagai tujuan wisata. Pariwisata merupakan berbagai kegiatan wisata yang ditunjang adanya berbagai sarana yang diberikan kepada wisatawan yang berkunjung di tujuan wisata (Undang-Undang RI nomor 10 tahun 2009).

Sejalan perkembangan sekarang ini, pariwisata mengalami perkembangan dengan berbagai pendekatan, seperti: sustainable tourism development, rural tourism, ecotourism, sebagai pengembangan wisata tidak hanya di perkotaan namun bisa dilakukan di daerah tujuan wisata. Suwena (2010) menyatakan bahwa pengembangan wisata alternatif salah satunya adalah desa wisata untuk pembangunan pedesaan yang berkelanjutan dalam bidang pariwisata. Desa wisata sebagai kumpulan masyarakat swadaya dan swakarsa yang memiliki kegiatan sosial dengan tujuan untuk meningkatkan pengetahuan kegiatan kepariwisataan, menampung partisipasi masyarakat dalam mengembangkan kepariwisataan di suatu wilayah, meningkatkan perekonomian masyarakat serta ikut mendukung keberhasilan kepariwisataan. Desa wisata menurut Darsono (2005) merupakan area pedesaan yang memiliki sosial budaya, kebiasaan, tata bangunan yang masih asli sebagai bagian komponen pariwisata yang disajikan secara terintegrasi dengan pertunjukkan, akomodasi serta sarana dan prasarana.

Desa wisata merupakan alternatif produk wisata yang dapat mendorong pengembangan pedesaan serta memiliki dasar pengelolaan, seperti: memanfaatkan prasarana dan sarana yang ada, memberikan manfaat bagi masyarakat setempat, memberdayakan masyarakat, dan mengimplementasikan hasil wisata desa (Muliawan, 2008).

Desa Banjarsari Kecamatan Manyar Kabupaten Gresik memiliki potensi pada hasil pertanian maupun non pertanian (seperti: tambak) dan memiliki peluang dari sisi sarana dan prasarana untuk berkembang menjadi desa wisata. Potensi merupakan daya tarik yang dimiliki oleh suatu daerah tujuan wisata agar wisatawan tertarik untuk berkunjung ke tempat tersebut (Mariotti dalam Yoeti (1996). Berbagai upaya dilakukan dalam mewujudkan masyarakat desa yang memiliki kesadaran sebagai desa wisata. Pemerintah Desa Banjarsari Kecamatan Manyar Kabupaten Gresik turut berperan aktif dalam mewujudkan sebagai desa wisata. 
Desa Banjarsari Kecamatan Manyar Kabupaten Gresik dalam mewujudkan sebagai desa wisata bukanlah hal yang mudah, tidak cukup hanya memperhatikan pembenahan pembangunan fisik, namun lebih dari pada itu diperlukan kesiapan sumber daya manusianya. Memahami permasalahan yang dihadapi tersebut maka kualitas sumber daya manusia harus ditingkatkan berkaitan dengan kemampuan, pengetahuan, dan ketrampilan agar dapat menunjang keberhasilan kepariwisataan desa.

Sumber daya manusia berkualitas tinggi menurut (Tannady, 2017:29) adalah sumber daya manusia yang memberikan value kompetitif, seperti: kompetensi, kreativitas, dan imajinasi. Sumber daya manusia yang berkualitas adalah individu yang memiliki kemampuan, pengetahuan, kompetensi, dan ketrampilan dalam menghasilkan kualitas layanan yang memuaskan (Desler, 2015:15).

\section{METODE PELAKSANAAN}

Pelaksanaan kegiatan ini menggunakan pendekatan eksploratif diskripstif tentang permasalahan yang dihadapi mitra melalui solusi yang didasarkan pada wawancara dan pendekatan kajian literatur.

Pemberian solusi permasalahan kepada mitra menggunakan metode pelaksanaan kegiatan sebagai berikut:

1. Survei lokasi

Kegiatan ini dilakukan dengan maksud untuk mengetahui permasalahan yang dihadapi oleh mitra dan untuk mengetahui potensi Desa Banjarsari Kecamatan Manyar Kabupaten Gresik.

2. Sosialisasi kegiatan dan diskusi

Metode ini digunakan untuk menyampaikan informasi kepada mitra tentang pelaksanaan kegiatan terkait tujuan, penyampaian materi, dan tahapan pelaksanaan kegiatan. Kegiatan diskusi dilakukan dengan tanya jawab. Materi yang disampaikan berkaitan peningkatan kualitas sumber daya manusia dalam pengelolaan desa wisata.

3. Penyuluhan

Kegiatan penyuluhan dilakukan dengan menggunakan ceramah untuk meningkatkan kualitas mitra dalam pengembangan desa wisata dan cara memberikan pelayanan yang baik kepada wisatawan.

4. Pelatihan

Kegiatan pelatihan bagi masyarakat yang terlibat dalam pengelolaan desa wisata untuk pembuatan dan penggunaan website sebagai salah satu bagian promosi dan pemberian layanan yang baik kepada wisatawan.

5. Evaluasi Kegiatan

Pada tahap ini dilakukan sebagai upaya untuk melihat keberhasilan dari program yang telah dilakukan melalui wawancara dengan mitra dan melaksanakan monitoring terhadap pelaksanaan program yang telah dilakukan mitra secara berkala. 


\section{HASIL DAN PEMBAHASAN}

Berdasarkan uraian permasalahan yang dihadapi mitra maka terdapat beberapa penyelesaian permasalahan mitra yang berhubungan dengan peningkatan kualitas sumber daya manusia, yaitu:

1. Keterlibatan masyarakat setempat yang saling mendukung dalam menciptakan keamanan dan kenyamanan bagi wisatawan yang berkunjung sangat diperlukan dalam mewujudkan sebagai desa wisata. Keterlibatan masyarakat dapat di dilakukan melalui rencana yang baik, pengelolaan, dan melakukan evaluasi terhadap kegiatan yang sudah dilaksanakan (Cohen dan Uphoff, 1979). Dalam pengembangan sebagai desa wisata diperlukan kemampuan dalam pengelolaan dalam berbagai aspek. Usaha peningkatan kemampuan masyarakat dilakukan dengan meningkatkan kompetensi dan wawasan pengetahuan masyarakat dan informasi dalam mengembangkan potensi yang ada. Hal tersebut dilakukan dengan memberikan penyuluhan bagi masyarakat dalam pengembangan desa wisata. Masyarakat diajarkan bagaimana mengelola wisata, memberikan pelayanan yang baik kepada wisatawan, seperti: menyediakan sarana dan prasarana yang baik, memberikan produk desa wisata, dan meningkatkan kemampuan berkomunikasi kepada para wisatawan. Komunikasi berperan penting dalam kegiatan pariwisata yang fokus pada layanan untuk menciptakan kesan positif terhadap wisatawan dapat datang.

2. Dalam rangka pengembangan Desa Banjarsari Kecamatan Manyar Kabupaten Gresik sebagai desa wisata maka dibutuhkan kegiatan promosi. Kegiatan promosi bertujuan untuk mengenalkan citra Desa Banjarsari Kecamatan Manyar Kabupaten Gresik sebagai desa wisata sehingga mampu meningkatkan jumlah wisatawan yang datang. Oleh karena itu, promosi melalui media online sangat dibutuhkan. Berdasarkan hasil survei diketahui bahwa Desa Banjarsari Kecamatan Manyar Kabupaten Gresik belum memiliki sarana promosi sehingga perlu dibuatkan website. Website tersebut dapat digunakan sebagai sarana promosi yang efektif dan dapat melayani wisatawan yang melakukan pemesanan tiket secara online. Pemanfaatan website sebagai salah satu sarana dalam meningkatkan kualitas layanan kepada wisatawan. Masyarakat di Desa Banjarsari Kecamatan Manyar Kabupaten Gresik yang terlibat dalam pengelolaan website desa wisata akan diberikan pelatihan sehingga dapat meningkatkan wawasan mengenai website.

3. Memberikan pelatihan kepada masyarakat dalam pengolahan hasil perikanan dan pertanian yang merupakan ciri khas wilayah Gresik, seperti: bandeng diolah menjadi otak-otak atau bandeng asap dan kue pudak dan lainnya. Kegiatan ini dilakukan sebagai usaha menumbuhkan rasa percaya diri dan meningkatkan ketrampilan masyarakat dalam memperluas kegiatan usaha. Hasil yang diharapkan agar dapat meningkatkan perekonomian masyarakat setempat khususnya menjadi lebih baik dan memperluas lapangan pekerjaan. 


\section{Gambar 1.}

Tim Penyuluh Pengabdian Masyarakat
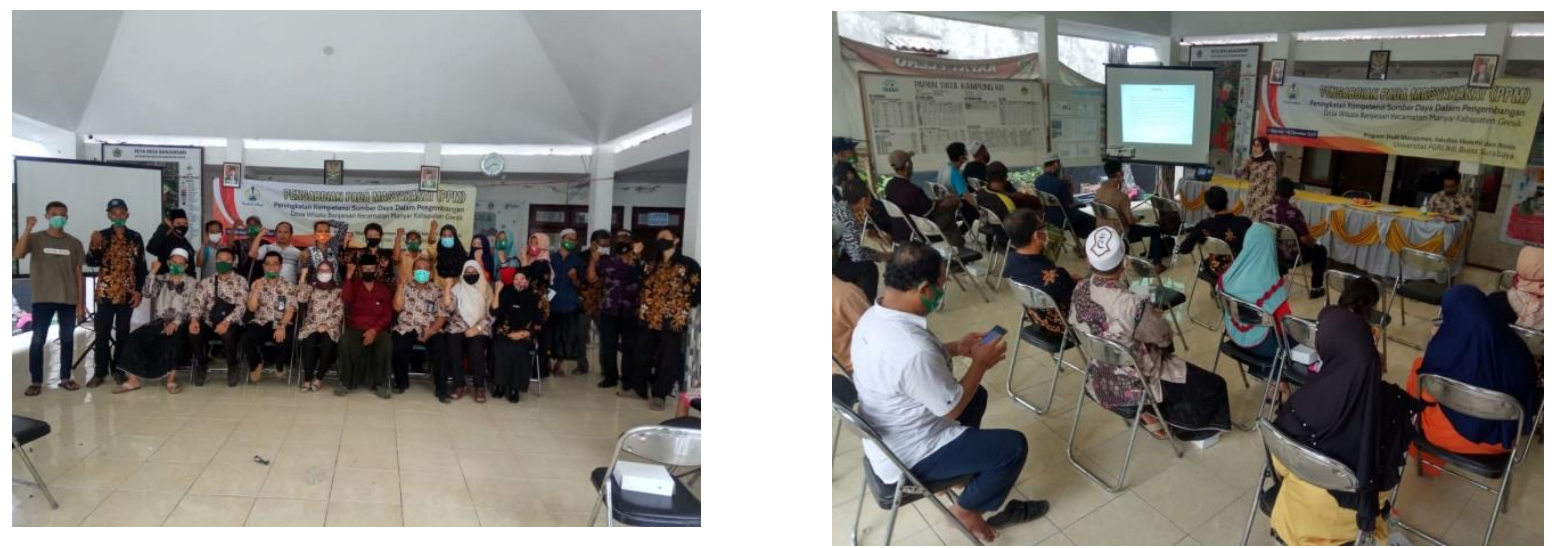

\section{DAMPAK DAN MANFAAT KEGIATAN}

\section{Dampak}

Dampak dari kegiatan yang dilakukan bagi masyarakat adalah:

1. Peningkatan kemampuan dalam berkomunikasi dalam melayani wasatawan.

2. Masyarakat mampu memahami, memanfaatkan, dan membuat teknologi website sebagai sarana kegiatan promosi.

3. Adanya pengingkatan ketrampilan dalam pengelolaan makanan sebagai ciri khas yang dimiliki masyarakat setempat.

4. Meningkatkan perekonomian masyarakat dengan adanya desa wisata.

\section{Manfaat}

Kegiatan Pengabdian Kepada Masyarakat memberikan beberapan manfaat, yaitu:

1. Masyarakat di Desa Banjarsari Kecamatan Manyar Kabupaten Gresik dapat meningkatkan wawasan pengetahuan dan ketrampilan tentang kepariwisataan.

2. Terwujudnya Desa Banjarsari sebagai desa wisata akan dapat mendukung pariwisata kerakyatan.

Menumbuhkan kesadaran masyarakat akan pentingnya tehnologi informasi digitalisasi dalam berbagai aktivitas

\section{SIMPULAN}

\section{Kesimpulan}

Program-program PPM telah berjalan baik dan lancar. Masyarakat di Desa Banjarsari Kecamatan Manyar Kabupaten Gresik menyambut baik dan antusias diberikan penyuluhan dan pelatihan dalam usaha pengembangan sebagai desa wisata. Program penyuluhan dan pelatihan telah memberikan dampak positif pada peningkatan pengetahuan, kemampuan, ketrampilan yang dimiliki masyarakat setempat berkaitan dengan desa wisata dan juga memiliki kemampuan untuk membuat website sebagai kegiatan promosi melalui media online. 


\section{Saran}

Kegiatan pengabdian kepada masyarakat diharapkan dapat dilakukan secara berkesinambungan untuk dapat membantu masyarakat Desa Banjarsari Kecamatan Manyar Kabupaten Gresik dalam mewujudkan sebagai desa wisata. Pengembangan desa wisata memerlukan partisipasi aktif dari masyarakat untuk terus ditumbuhkan.

\section{UCAPAN TERIMA KASIH}

Terlaksananya kegiatan tersebut atas kerjasama yang baik dari berbagai unsur, sehingga kami sampaikan rasa terima kasih untuk:

1. Lembaga Penelitian dan Pengabdian Masyarakat Universitas PGRI Adi Buana Surabaya atas pendanaan internal yang telah diberikan kepada tim Pengabdian Masyarakat.

2. Pimpinan Fakultas Ekonomi dan Bisnis yang telah memberikan dukungan dalam pelaksanaan pengabdian masyarakat.

3. Kepala Desa Banjarsari Kecamatan Manyar Kabupaten Gresik atas kesediaannya memberikan kesempatan waktu dan tempat kepada tim dalam melaksanakan kegiatan pengabdian masyarakat.

4. Tim Dosen selaku pemateri dan mahasiswa selaku pelaksana kegiatan yang telah melaksanakan kegiatan pengabdiaan masyarakat dengan baik.

\section{DAFTAR PUSTAKA}

Cohen, E., \& Uphoff. (1974). Who is a Tourist? A Conceptual Clarification. The Sociological Review, 22 (4), 527- 555.

Darsono. (2005). Pengertian Desa. Diunduh tanggal 10 Maret 2014 dari: http://desasentonorejo.wordpress.com/bab-ii/

Dessler. Gary. (2015). Manajemen Sumber daya Manusia. Edisi 14. Salemba Empat, Yogyakarta.

Tannady, Hendy. (2017). Manajemen Sumber Daya Manusia. Cetakan Ke-1. Expert, Yogyakarta.

Kementrian Pariwisata. (2020). https://lokadata.beritagar.id/chart/preview/kontribusipariwisata-terhadap-pdb-2010-2019-1582001327

Muliawan. (2008). Pengembangan Pariwisata Berbasis Masyarakat Konsep dan Implementasi, tanpa kota: tanpa penerbit.

Nourse, Hugh O. (1968). Regional Economics: A Study in the Economic Structure, Stability, and Growth of Regions. McGraw-Hill Book Company, New York. Suwena, I Ketut. (2010). Pengetahuan Dasar Ilmu Pariwisata. Denpasar: Udayana Press. Undang - Undang Republik Indonesia Nomor 10 Tahun 2009 tentang Kepariwisataan. Yoeti, Oka A.(1996). Pengantar Ilmu Pariwisata. Bandung: Angkasa. 